\title{
DOES DEBT MATURITY MATTER FOR INVESTMENT DECISIONS?
}

\author{
CHANG WOON NAM \\ DOINA MARIA RADULESCU
}

CESIFO WORKING PAPER NO. 1124

CATEGORY 1: PUBliC FinANCE

FEBRUARY 2004

An electronic version of the paper may be downloaded

- from the SSRN website:

- from the CESifo website:

www.SSRN.com

www.CESifo.de 


\title{
DOES DEBT MATURITY MATTER FOR INVESTMENT DECISIONS?
}

\begin{abstract}
In the conventional literature related to investment decisions, less attention has been paid to the length of maturity when investment is debt-financed. In such a case a firm pays the creditor not only the sum of annual interest (initial investment cost multiplied by real interest rate) for the entire borrowing years but also the total amount of initial investment cost at the end of the borrowing period. In this study, the effects of selecting different maturity years on firms' investment decisions are compared on the basis of the simple net present value (NPV) model. Without taxation, the NPV is equal to the present value (PV) of future gross return less the PV of the cost of investment. An investment project is considered to be profitable when the NPV is positive. After the introduction of a corporate income tax, the PV of an asset amounts to the sum of PVs of net return (gross return less taxes) and tax savings led by an incentive depreciation provision. If the investment is debt-financed, the interest payment additionally reduces the corporate tax base. The research findings suggest that (1) ceteris paribus an optimum maturity year appears to exist that maximises the NVP, and (2) the change of optimum debt maturity tends to correlate positively with the corporate tax rate but negatively with the interest rate. In the case of prevailing inflation, there is a mismatch between the nominal interest rate that is a discounting factor for all observed in- and outflows and the real interest rate by which the annual interest payment is determined for the entire maturity period.
\end{abstract}

JEL Classification: H25, H32, M21, G31.

Keywords: debt maturity, investment decision, net present value, corporate taxation, inflation.

Chang Woon Nam

Ifo Institute for Economic Research

Poschinger Str. 5

81679 Munich

Germany

nam@ifo.de
Doina Maria Radulescu

Ifo Institute for Economic Research

Poschinger Str. 5

81679 Munich

Germany

radulescu@ifo.de 


\section{Introduction}

In the corporate finance literature it is suggested that maturity of debt in forms of bank credit and bond can play an important role in reducing costs associated with debt financing (Ozkan, 2000). When investment is debt-financed, an investing firm pays the creditor not only the sum of annual interest (i.e. initial investment cost multiplied by the real interest rate) for the entire borrowing years but also the total amount of initial investment cost at the end of the borrowing period.

Among previous research works on this matter, Goswami, Noe and Rebello (1995) argue that long-term debt is the preferred financing instrument of choice when the degree of asymmetric information increases over time. A positive correlation is also often observed between the size of firm and debt maturity as shown by Jalilvand and Harris (1984). Issuing costs of a public bond are fixed for the largest part and therefore are independent of the magnitude of debt. This enables the realisation of economies of scale. For this reason, larger firms will issue public debt which generally has a longer maturity

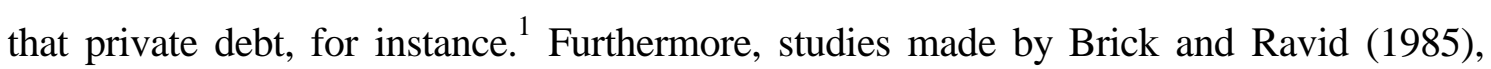
Kane, Marcus and McDonald (1985), and Scholes and Wolfson (1992) highlight the parallel development of the interest tax shield on debt (consequently the value of firm) and the term structure of debt. When the term structure of the interest rate slopes upward, longterm debt is optimal since the saving from leverage due to the interest tax shield is accelerated (borrower's incentive) and recognition of interest income is delayed (lender's incentive). By contrast, a negative relation of debt maturity appears to be pronounced with growth opportunity (Myers, 1977; Titman, 1992). The short-term debt mitigates the underinvestment problem ${ }^{2}$ if it matures before growth options are exercised, as there remains an opportunity for lenders and borrowers to re-contract. Firms with a better credit

1 Larger firms also appear to have lower agency costs. According to Smith and Warner (1979), small firms are more likely to face potential conflict of interest between a firm's shareholders and bondholders such as risk shifting and claim dilution. This problem can be reduced by issuing more shorter-term debts. Moreover larger firms have a much easier access to the capital markets (Titman and Wessels, 1988), and small firms are generally precluded from accessing long-term debt markets, since the proportion of their collateralisable assets to future investment opportunities is relatively small (Whited, 1992).

2 According to Myers (1977), it is possible under debt financing that managers do not carry out investment with a positive net present value. When leverage is high, residual claims will be very low and profits from investment will only benefit creditors. Managers will be reluctant to pursue future investments which, however, reduce the investment opportunity set and ultimately firm value. 
record tend to borrow on the long-term (Flannery, 1986; Mitchell, 1991). A high liquidity ratio may reduce the fund raising capacity of the firms as excessive liquidity reduces managers' ability to commit credibly to an investment activity, which will, in turn, shorten the maturity for available debts (Diamond, 1991; Myers and Rajan, 1998). The principle of matching debt and asset maturity has traditionally been acknowledged as a useful benchmark for selecting the borrowing years, because in this way the risk that cash inflows are insufficient to cover the interest payments and capital outlays is reduced (Morris, 1976; Myers, 1977; Hart and Moore, 1994; Stohs and Mauer, 1996; Emery, 2001). . $_{\text {Leland and }}$ Thoft (1996) show that optimal leverage depends on debt maturity and is lower when the firm is financed by short-term debt. Furthermore, debt maturity is determined as a result of a trade-off between tax advantages and leverage-related costs, including agency costs, suggesting that riskier firms should issue short-term debt in addition to using less debt.

This study begins with revisiting the Miller-Modigliani paper (1958) which demonstrates that not only the capital structure of a firm but also debt maturity is irrelevant in a perfect capital market. Unlike the theoretical and empirical investigations mentioned above, this study suggests a possibility of an optimal debt maturity year, which delivers ceteris paribus the maximum net present value. Furthermore, it aims at elaborating the sensitivity of optimum debt maturity to the variation of corporate tax, interest and inflation rates.

The present value model is a well-known basic investment decision model. Without taxation, the net present value (NPV) is equal to the present value of future gross return, discounted at an appropriate interest rate less the present value of the cost of investment. An investment project is therefore considered to be profitable when the NPV is positive. After the introduction of tax on corporate income, the annual tax base is reduced by the sum of annual interest payments, whereas the discount rates also declines with the tax rate. A tax paradox occurs when tax depreciation is greater than Samuelson's true economic depreciation (TED). Under the assumption of a perfect competitive market structure, only one interest rate exists in the financial market. In the case of prevailing inflation, there is a mismatch between the nominal interest rate that is a discounting factor for all observed inand outflows and the real interest rate by which the annual interest payment is determined 
for the entire maturity period.

\section{Modigliani-Miller Theorem of Capital Structure Revisited}

Miller and Modigliani (1958) asserted that under certain assumptions such as (1) perfect markets (i.e. no taxes or transaction costs), (2) cash flows that are independent of financial structure, and (3) riskless debt such that firms and individuals can borrow and lend at a risk free interest rate, the market value of a firm is independent of its capital structure. This theory can also be illustrated in terms of the present value model as follows.

Assume that for equity-finance the following condition is satisfied in the equilibrium

$$
\Psi_{0}=\mathrm{C}
$$

where $\Psi_{0}$ is the present value of future gross return at year 0 generated by an investment costing C.

In the case of financing $C$ through debt, a firm pays the creditor not only the annual interest of $\mathrm{rC}$ for s years long but also the entire amount of $\mathrm{C}$ to the creditor at the end of this borrowing period. Therefore, the present value of total cost at year $0\left(\mathrm{C}^{*}\right)$ can be expressed:

$$
\begin{aligned}
\mathrm{C}^{*} 0 & =\int_{0}^{\mathrm{s}} \mathrm{rCe} \\
& =\left(1-\mathrm{e}^{-\mathrm{rs}}\right) \mathrm{du}+\mathrm{Ce}^{-\mathrm{rs}}=\mathrm{C}
\end{aligned}
$$

where $\mathrm{r}=$ real interest rate $(0<\mathrm{r}<1)$ and $\mathrm{s}=$ debt maturity years $(\mathrm{s}>0)$.

Hence, in the absence of tax, for example, the condition shown in equation (II-1) applies in the equilibrium regardless of the financial structure (i.e. $\mathrm{C}^{*}{ }_{0}=\mathrm{C}=\Psi_{0}$ ). At the same time equation (II-2) suggests that the debt maturity is also irrelevant under the 
assumed capital market condition.

In the equilibrium without tax, equation (II-3) additionally proves that inflation does not matter for financial decision-making either if the annual interest payment is made based on the nominal interest rate for s years long.

$$
\begin{aligned}
\mathrm{nC}^{*} 0 & =\int_{0}^{\mathrm{s}}(\mathrm{r}+\pi) C \mathrm{e}^{-(\mathrm{r}+\pi) \mathrm{u}} \mathrm{du}+\mathrm{Ce} \mathrm{e}^{-(\mathrm{r}+\pi) \mathrm{s}} \\
& =(\mathrm{r}+\pi) \mathrm{C}\left\{\frac{1-\mathrm{e}^{-(\mathrm{r}+\pi) \mathrm{s}}}{\mathrm{r}+\pi}\right\}+\mathrm{Ce}^{-(\mathrm{r}+\pi) \mathrm{s}}=\mathrm{C}=\Psi_{0}
\end{aligned}
$$

where $\mathrm{nC}^{*}{ }_{0}=$ the nominal present value of total cost at year 0 and $\pi=$ inflation rate $(0<\pi$ $<1)$.

If the interest payment takes place annually, applying the real interest rate in spite of prevailing inflation, as it is the case in practice, then

$$
\begin{aligned}
\mathrm{nC}^{*}{ }_{0} & =\int_{0}^{\mathrm{s}} \mathrm{rCe} \\
& =\mathrm{rC}\left\{\frac{1-\mathrm{e}^{-(\mathrm{r}+\pi) \mathrm{s}}\left\{\frac{\mathrm{C}}{\mathrm{r}+\pi} \mathrm{du}+\mathrm{Ce}^{-(\mathrm{r}+\pi) \mathrm{s}}\right.}{\mathrm{r}+\pi}\left\{\mathrm{r}+\pi \mathrm{e}^{-(\mathrm{r}+\pi) \mathrm{s}}\right\}<\mathrm{C}\right.
\end{aligned}
$$

\section{Optimal Debt Maturity Revealed in Net Present Value Model}

\section{III.1 Without Inflation}

Under the assumption that

- an investment costing $\mathrm{C}$ generates an infinite stream of future gross return, 
- this return exponentially declines at the rate $\alpha(0<\alpha<1)$ 田

- all prices are constant over time $(\pi=0)$,

a debt-financed investment project is on the margin of acceptance in the absence of taxation, when

$$
\begin{gathered}
\mathrm{Ce}^{-\mathrm{rs}}=\int_{0}^{\infty} \mathrm{A}_{0} \mathrm{e}^{-(\alpha+\mathrm{r}) \mathrm{u}} \mathrm{du}-\int_{0}^{\mathrm{s}} \mathrm{rCe} \mathrm{e}^{-\mathrm{ru}} \mathrm{du} \\
=\frac{\mathrm{A}_{0}}{\alpha+\mathrm{r}}-\left(1-\mathrm{e}^{-\mathrm{rs}}\right) \mathrm{C}
\end{gathered}
$$

where $\mathrm{A}_{0}=$ gross return at the year of investment.

Consequently,

$$
\Psi_{0}=\frac{\mathrm{A}_{0}}{\alpha+\mathrm{r}}=\mathrm{C}
$$

In this case, the net present value $\mathrm{Y}\left(=\Psi_{0}-\mathrm{C}\right)$ amounts to zero.

After the introduction of a tax on corporate income $(\mathrm{t})$, the annual tax base is reduced by the sum of the annual interest payment, whereas the discount rate is also reduced by the tax rate. Samuelson (1964) showed in his fundamental theorem of tax-rate invariance that corporate income taxation does not affect firms' investment decisions at all, when true economic depreciation (TED) - the negative change in value of asset in the course of time - is deducted from an expected gross stream of return when calculating tax profits, and when the TED rate is the same as $\alpha$. In other words, a tax paradox occurs when the tax depreciation is greater than TED (King, 1977; Atkinson and Stiglitz, 1980; King and Fullerton, 1984; Sinn, 1987).

4 The assumption of declining gross return in the course of time is often made in practice, because it is hardly possible to forecast the development of future profit. This type of assumption appears to be more plausible than the one with constant annual profit. 
The amount of geometric-degressive depreciation expense in the period $u$ is measured

$$
\mathrm{D}_{\mathrm{u}}^{\mathrm{gdd}}=\delta \mathrm{Ce} \mathrm{e}^{-\delta \mathrm{u}}
$$

where $\delta$ is the geometric-degressive depreciation rate $(0<\delta<1)$ and $\mathrm{Ce}^{-\delta \mathrm{u}}$ shows the net book value of capital good in the period $u$.

Hence, with debt finance and geometric-degressive depreciation, the net present value of the asset at time 0 is

$$
\begin{aligned}
& Y=(1-t) \int A_{0} e^{-\{\alpha+r(1-t)\} u} d u-(1-t) \int r^{s} e^{-r(1-t) u} d u+t C \int \delta e^{-\{\delta+r(1-t)\} u} d u-C e^{-r s} \\
& 0 \quad 0 \quad 0 \\
& =\frac{\mathrm{A}_{0}}{\alpha+\mathrm{r}}+\mathrm{tC}\left\{\frac{\delta}{\delta+\mathrm{r}(1-\mathrm{t})}-\frac{\alpha}{\alpha+\mathrm{r}(1-\mathrm{t})}\right\}-\left\{1-\mathrm{e}^{-\mathrm{r}(1-\mathrm{t}) \mathrm{s}}\right\} \mathrm{C}-\mathrm{Ce}^{-\mathrm{rs}}
\end{aligned}
$$

When $\delta>\alpha$, geometric-degressive depreciation provides incentives.

There is an optimal debt maturity $\mathrm{s}^{*}$ when the first order condition of equation (III-4) is zero and its second derivation is negative:

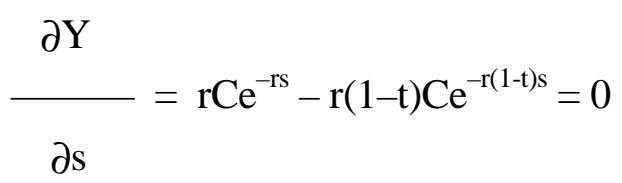

The second derivation of equation (III-4) is always smaller than zero

$$
\frac{\partial^{2} \mathrm{Y}}{\partial \mathrm{s}^{2}}=-\mathrm{r}^{2} \mathrm{Ce}^{-\mathrm{rs}}+\mathrm{r}^{2}(1-\mathrm{t})^{2} \mathrm{Ce}^{-\mathrm{r}(1-\mathrm{t}) \mathrm{s}}<0
$$

since the sum of $\mathrm{r}^{2} \mathrm{Ce}^{-\mathrm{rs}}$ is always larger than the second term of equation (III-6) by the given parameter constellation. 
Therefore, the optimal debt maturity $\mathrm{s}^{*}$ can be derived from equation (III-5)

$$
\mathrm{s}^{*}=\frac{\ln (1 / 1-\mathrm{t})}{\mathrm{rt}}
$$

The sensitivity of $\mathrm{s} *$ in relation to the changes of $\mathrm{r}$ can be expressed

$$
\frac{\partial s^{*}}{\partial r}=-\frac{\ln (1 / 1-t)}{r^{2} t}<0
$$

Ceteris paribus the condition shown in equation (III-8) is always smaller than zero, implying the negative correlation between $\mathrm{s}^{*}$ and $\mathrm{r}$.

The optimal debt maturity s* varies also when $t$ changes

$$
\frac{\partial \mathrm{s}^{*}}{\partial \mathrm{t}}=\frac{1}{\mathrm{rt}(1-\mathrm{t})}-\frac{\ln (1 / 1-\mathrm{t})}{\mathrm{rt}^{2}}>0
$$

By the given parameter selection the first term of equation (III-9) is always larger than the second one. Thus equation (III-9) demonstrates the positive relationship between $\mathrm{s}^{*}$ and $\mathrm{t}$.

\section{III.2 With Inflation}

In an economy with a constant inflation rate $\pi$, the stream of gross return which is generated by an investment costing $\mathrm{C}$ at time $\mathrm{u}$ is

$$
\mathrm{A}_{\mathrm{u}}=\mathrm{A}_{0} \mathrm{e}^{-\alpha \mathrm{u}} \mathrm{e}^{\pi \mathrm{u}}=\mathrm{A}_{0} \mathrm{e}^{-(\alpha-\pi) \mathrm{u}}
$$

In this case, the sum of annual gross return exponentially decreases at the rate $\alpha(0<\alpha<$ 1) but increases at the rate $\pi$ in the course of time.

When employing the historical accounting method, the nominal net present value at the 
year 0 is

$$
\begin{aligned}
& Y(n)=(1-t) \int A_{0} e^{-\{(\alpha-\pi)+\mu(1-t)\} u} d u-(1-t) \int r^{\infty} e^{-\mu(1-t) u} d u+t C \int \delta e^{-\{\delta+\mu(1-t)\} u} d u \\
& 0 \quad 0 \quad 0 \\
& -\mathrm{Ce}^{-\mu \mathrm{s}} \\
& =\frac{\mathrm{A}_{0}}{(\alpha-\pi)+\mu}+\mathrm{tC}\left\{\frac{\delta}{\delta+\mathrm{r}(1-\mathrm{t})}-\frac{\alpha}{\alpha+\mathrm{r}(1-\mathrm{t})}\right\}-\frac{\mathrm{r}}{\mu}\left\{1-\mathrm{e}^{-\mu(1-\mathrm{t}) \mathrm{s}}\right\} \mathrm{C}-\mathrm{Ce}^{-\mu \mathrm{s}}
\end{aligned}
$$

where $\mu=$ nominal interest rate $(=r+\pi)$.

When the first order condition of equation (III-11)

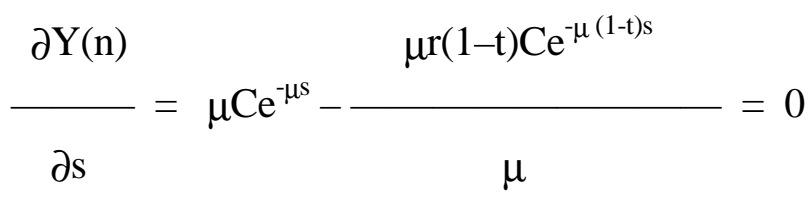

subject to

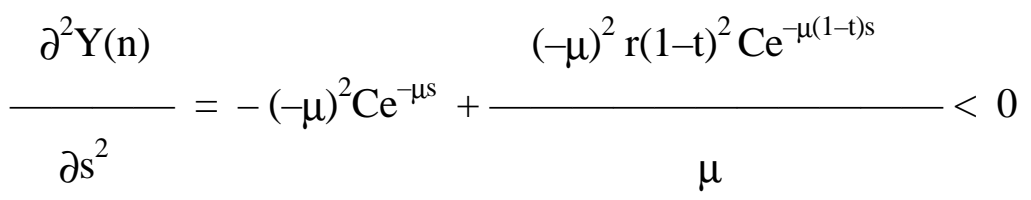

5 Under historical cost accounting, the capital to be recovered before a profit is recognised as simply the amount of money originally invested in the firm. Historical profit is, therefore, the current period's revenues minus the historical cost of the inputs necessary to secure them, the current period's expenses. It has long been recognised that increases in input prices can cause historical cost accounting to seriously overstate a firm's ability to distribute its reported profits, continue producing the same physical volume of goods and services, and understate the firm's capital. The application of the historical cost accounting method when calculating the corporate tax base causes fictitious profits in inflationary phases that are also subject to tax. Therefore, in periods with inflation generous tax depreciation provisions do not adequately promote private investment as intended but only (or partly) compensate the losses caused by inflation (Aaron, 1976; Kay, 1977; Feldstein, 1979; Kopcke, 1981; Gonedes, 1984; Nam and Radulescu, 2003). 
then the optimum debt maturity $\mathrm{s}(\mathrm{n})^{*}$ exists

$$
\mathrm{s}(\mathrm{n})^{*}=\frac{\ln [\mu /\{\mathrm{r}(1-\mathrm{t})\}]}{\mu \mathrm{t}}
$$

The optimal debt maturity $\mathrm{s}(\mathrm{n}) *$ varies according to $\pi$

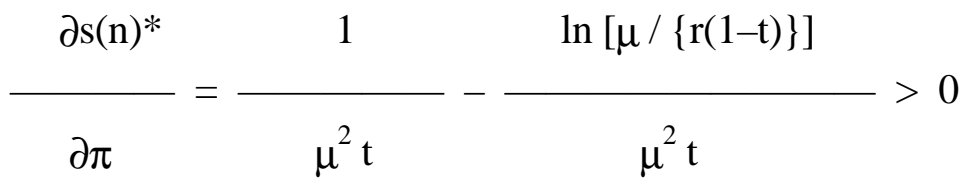

Equation (III-15) is always positive by the given parameter selection and suggests the parallel development of $\mathrm{s}(\mathrm{n}) *$ with $\pi$.

\section{Model Simulation}

Firstly we consider the case without inflation. Table 1 shows the changes of (real) net present value with geometric-degressive depreciation (Y) according to the debt maturity period (s). For the calculation three corporate tax rates are considered (i.e., $\mathrm{t}=15 \%, 25 \%$ and $35 \%$ ). Ceteris paribus the decrease in (real) interest rate from $8 \%$ to $4 \%$ leads to the changes in the margin of acceptance for the investment project. The TED rate $(=\alpha)$ is assumed to be $20 \%$, whereas $\delta$ amounts to $30 \%$, meaning that in our partial model simulation tax depreciation provides investment incentives. Taking the case with $\mathrm{t}=35 \%$ and $\mathrm{r}=8 \%$ as an initial one, $\mathrm{s}^{*}$ is around 16 years with $\mathrm{Y}=63$. The change of $\mathrm{r}$ to $4 \%$ increases $\mathrm{s}^{*}$ to about 30 years (with $\mathrm{Y}=71$ ), as already indicated in equation (III-8). With $\mathrm{r}=4 \%$ the decrease in $\mathrm{t}$ from $35 \%$ to $25 \%$ (or $15 \%$ ) leads to the decrease in s* to 28 years with $\mathrm{Y}=28$ (or $\mathrm{Y}=48$ ). This parallel relationship is technically expressed in equation (III-9). This empirical founding suggests that $\mathrm{s}^{*}$ reacts quite sensitively to the real interest

6 In a number of studies, including Sinn, Leibfritz and Weicherieder (1999), Bordignon, Giannini and Panteghini (1999), as well as Nam and Radulescu (2003), the economic asset life is (sometimes implicitly) assumed to be around 10 years for equipment. From this asset life one can derive $\alpha$ by the 
rate movement.

In a similar way Table 2 illustrates the changes of nominal net present values $\mathrm{Y}(\mathrm{n})$ caused by the variation of s. Apart from the standard assumptions made in Table 1, two inflation rates $(\pi=3 \%$ and $6 \%)$ are additionally taken into account in the computation implying that $\mu$ amounts to $7 \%$ and $11 \%$, respectively. In the case of adopting $t=25 \%$ and $\mathrm{r}=8 \%$, the falling $\pi$ from $6 \%$ to $3 \%$ leads to the decrease of $s(n) *$ from 24 years with $Y(n)$ $=165$ to 22 years with $Y(n)=115$. Such a movement appears to be less significant with $r$ $=4 \%$. 
Table 1 Optimal Debt Maturity in the Absence of Inflation

\begin{tabular}{|c|c|c|c|c|c|c|}
\hline \multirow[b]{3}{*}{$\mathrm{S}$} & \multicolumn{6}{|c|}{$\mathrm{Y}$} \\
\hline & \multicolumn{2}{|c|}{$t=15 \%$} & \multicolumn{2}{|c|}{$\mathrm{t}=25 \%$} & \multicolumn{2}{|c|}{$\mathrm{t}=35 \%$} \\
\hline & $\mathrm{r}=4 \%$ & $\mathrm{r}=8 \%$ & $\mathrm{r}=4 \%$ & $\mathrm{r}=8 \%$ & $\mathrm{r}=4 \%$ & $\mathrm{r}=8 \%$ \\
\hline 2 & 7.4 & 11.1 & 11.9 & 18.1 & 16.1 & 24.9 \\
\hline 4 & 11.3 & 16.4 & 18.6 & 27.3 & 25.6 & 38.1 \\
\hline 6 & 14.7 & 20.2 & 24.4 & 33.9 & 33.9 & 47.8 \\
\hline 8 & 17.6 & 22.7 & 29.3 & 38.4 & 41.0 & 54.6 \\
\hline 10 & 20.0 & 24.2 & 33.5 & 41.3 & 47.1 & 59.2 \\
\hline 12 & 22.0 & 24.9 & 37.0 & 42.8 & 52.3 & 61.9 \\
\hline 14 & 23.6 & 25.0 & 39.9 & 43.4 & 56.7 & 63.3 \\
\hline 16 & 24.9 & 24.7 & 42.2 & 43.2 & 60.3 & 63.4 \\
\hline 18 & 25.8 & 24.1 & 44.1 & 42.4 & 63.3 & 62.8 \\
\hline 20 & 26.6 & 23.3 & 45.6 & 41.2 & 65.6 & 61.5 \\
\hline 22 & 27.1 & 22.3 & 46.6 & 39.7 & 67.5 & 59.6 \\
\hline 24 & 27.4 & 21.2 & 47.4 & 38.0 & 68.9 & 57.5 \\
\hline 26 & 27.6 & 20.0 & 47.8 & 36.2 & 69.8 & 55.1 \\
\hline 28 & 27.6 & 18.9 & 48.0 & 34.3 & 70.4 & 52.6 \\
\hline 30 & 27.5 & 17.7 & 48.0 & 32.4 & 70.7 & 50.0 \\
\hline 32 & 27.2 & 16.6 & 47.8 & 30.5 & 70.6 & 47.4 \\
\hline 34 & 26.9 & 15.5 & 47.4 & 28.6 & 70.3 & 44.8 \\
\hline 36 & 26.5 & 14.5 & 46.9 & 26.9 & 69.8 & 42.2 \\
\hline 38 & 26.1 & 13.6 & 46.2 & 25.2 & 69.2 & 39.8 \\
\hline 40 & 25.5 & 12.7 & 45.5 & 23.6 & 68.3 & 37.4 \\
\hline 42 & 25.0 & 11.8 & 44.7 & 22.1 & 67.3 & 35.1 \\
\hline 44 & 24.4 & 11.0 & 43.7 & 20.6 & 66.2 & 33.0 \\
\hline 46 & 23.8 & 10.3 & 42.8 & 19.3 & 65.0 & 31.0 \\
\hline 48 & 23.1 & 9.7 & 41.8 & 18.1 & 63.7 & 29.1 \\
\hline 50 & 22.4 & 9.1 & 40.7 & 17.0 & 62.3 & 27.3 \\
\hline $\begin{array}{l}\text { Other } \\
\text { common } \\
\text { assumptions }\end{array}$ & $\begin{array}{l}\text { Debt finan } \\
\text { and } \delta=30\end{array}$ & $=416.7$ & $r=4 \%$ & $7.1 \mathrm{wi}$ & $8 \% ; \mathrm{A}_{0}=$ & $\alpha \alpha=20 \%$ \\
\hline
\end{tabular}

Source: Own calculations 
Table 2 Optimal Debt Maturity in Inflationary Phase

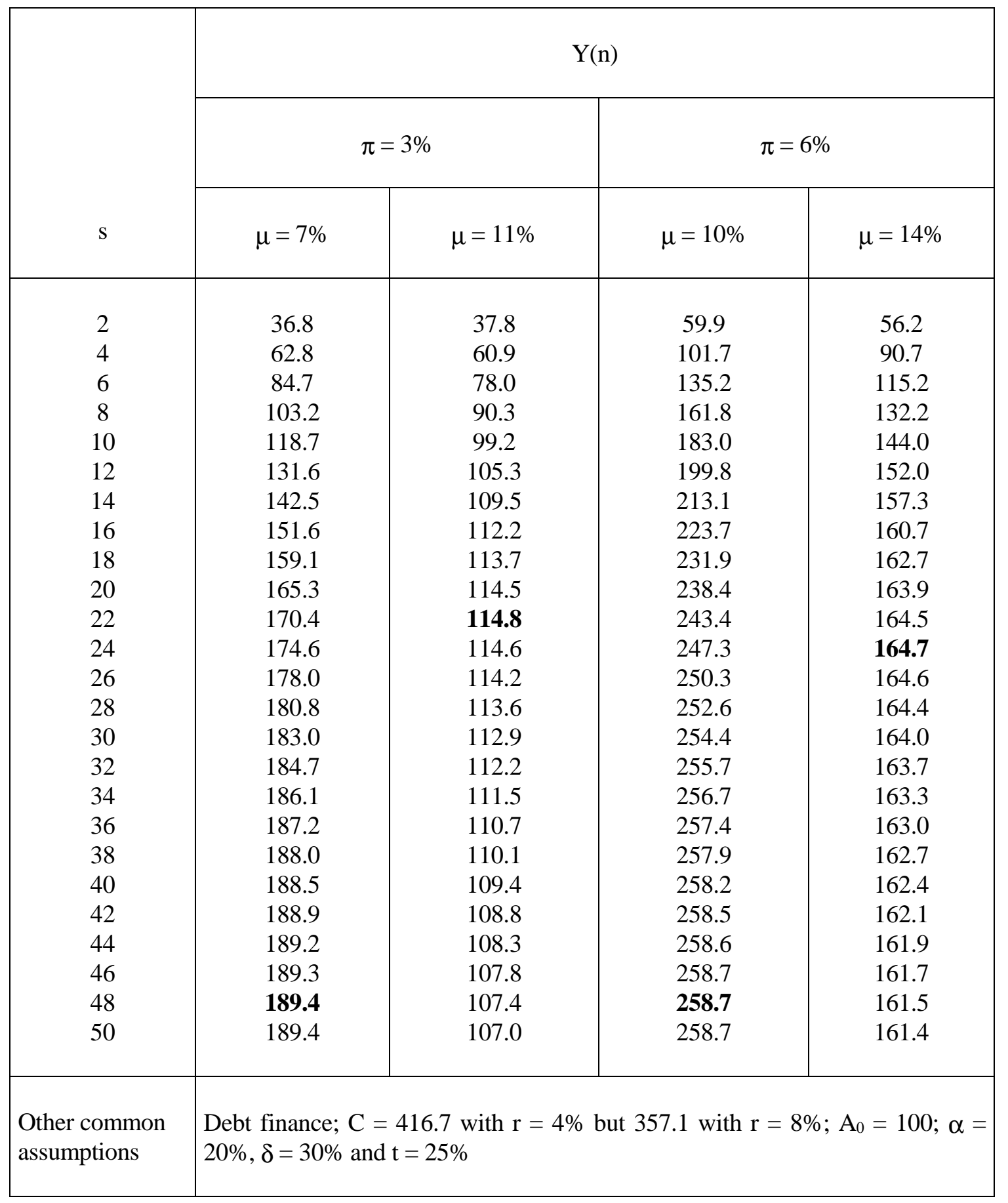

Source: Own calculations 


\section{Conclusion}

The selection of maturity years can play a significant role in reducing costs related to the debt-financed investment. In this case an investing firm pays the creditor the sum of annual interest for the borrowing years in addition to the repayment of the total amount of initial cost at the end of the borrowing period. Referring to the already existing theoretical framework suggesting different relationships of debt maturity with the determinants like firm size, growth opportunity, liquidity risk, creditworthiness, interest tax shield, asset maturity, leverage, agency costs, etc., the effects of choosing maturity years on firms' investment decisions are compared on the basis of the simple net present value (NPV) model. After the brief theoretical demonstration of the irrelevance of debt maturity in a perfect capital market, this study highlights the existence of optimum maturity $\mathrm{s}^{*}$ at which, ceteris paribus, the (real and nominal) NPV reaches a maximum. Furthermore, this study also elaborates the sensitivity of $s^{*}$ to the variation of corporate tax, interest and inflation rates. As also illustrated in the partial model simulation based on the selected parameters, the optimum debt maturity is correlated positively with the corporate tax rate but negatively with the interest rate. In the case of prevailing inflation, a further positive relationship is observed between $\mathrm{s}^{*}$ and the inflation rate.

\section{References}

Aaron, H. J. (1976), Inflation and the Income Tax: An Introduction, in: Aaron, H. J., (Ed.), Inflation and the Income Tax, Washington DC, The Brookings Institution: 1-31.

Atkinson, A. B. and J. E. Stiglitz (1980), Lectures on Public Economics, London, McGraw-Hill.

Brick, I. E. and S. A. Ravid (1985), On the Relevance of Debt Maturity Structure, Journal of Finance 40: 1423-1437.

Bordignon, M., S. Giannini and P. Panteghini (1999), Corporate Taxation in Italy: An Analysis of the 1998 Reform, Paper presented at the NHH-CESifo Norwegian-German Seminar on Public Economics on Capital Income Taxation, Munich, June 3-5, 1999.

Diamond, D. W. (1991), Debt Maturity Structure and Liquidity Risk, The Quarterly 
Journal of Economics 106: 709-737.

Emery, G. W. (2001), Cyclical Demand and the Choice of Debt Maturity, Journal of Business 74: 557-590.

Feldstein, M. S. (1979), Adjusting Depreciation in an Inflationary Economy: Indexing versus Acceleration, NBER Working Paper 395.

Flannery, M. J. (1986), Asymmetric Information and Risky Debt Maturity Choice, Journal of Finance 41: 19-37.

Gonedes, N. J. (1984), Evidence on the Tax Effect of Inflation under Historical Cost Accounting Methods, Journal of Business 54: 227-270.

Goswami, G., T. Noe and M. Rebello (1995), Debt Financing under Asymmetric Information, Journal of Finance 50: 633-659.

Hart, O. and J. Moore (1994), A Theory of Debt Based on the Inalienability of Human Capital, Quarterly Journal of Economics 109: 841-879.

Jalilvand, A. and R. S. Harris (1984), Corporate Behaviour in Adjusting to Capital Structure and Dividend Targets: An Econometric Study, Journal of Finance 39: 127145 .

Kane, A., A. J. Marcus and R. L. McDonald (1985), Debt Policy and the Rate of Return Premium to Leverage, Journal of Financial and Quantitative Analysis 20: 479-499.

Kay, J. A. (1977), Inflation Accounting: A Review Article, Economic Journal 87: 300311.

King, M. A. (1977), Public Policy and the Corporation, London, Chapman and Hall.

King, M. A. and D. Fullerton (1984), The Taxation of Income from Capital: A Comparative Study of the United States, the United Kingdom, Sweden and West Germany, Chicago, University of Chicago Press.

Kopcke, R. W. (1981), Inflation, Corporate Income Taxation and the Demand for Capital Asset, Journal of Political Economy 89: 122-131.

Leland H. E. and K. B. Thoft (1996), Optimal Capital Structure, Endogenous Bankruptcy, and the Term Structure of Credit Spreads, Journal of Finance 51: 987-1019.

Miller, M. H., and F. Modigliani (1958), The Cost of Capital, Corporation Finance and the Theory of Investment, American Economic Review 48: 261-297.

Mitchell, K. (1991), The Call, Sinking Fund and Term-to-maturity Features of Corporate Bonds: An Empirical Investigation, Journal of Financial and Quantitative Analysis 26: 
201-221.

Morris, J. R. (1976), On Corporate Debt Maturity Strategies, Journal of Finance 31, 2937.

Morris, J. R. (1992), Factors Affecting the Maturity Structure of Corporate Debt, Working Paper, College of Business Administration, University of Colorado at Denver.

Myers, S. C. (1977), Determinants of Corporate Borrowing, Journal of Financial Economics, 5: 147-175.

Myres, S. C. and R. G. Rajan (1998), The Paradox of Liquidity, Quarterly Journal of Economics 113: 733-771.

Nam, C. W. and D. M. Radulescu (2003), The Role of Tax Depreciation for Investment Decision: A Comparison of European Transition Countries, CESifo Working Paper 847.

Ozkan, A. (2000), An Empirical Analysis of Corporate Debt Maturity Structure, European Financial Management 6: 197-212.

Samuelson, P. A. (1964), Tax Deductibility of Economic Depreciation to Ensure Invariant Valuation, Journal of Political Economy 72: 604-606.

Scholes, M. S. and M. A. Wolfson (1992), Taxes and Business Strategy: A Planning Approach, Engelwood Cliffs, NJ, Prentice Hall.

Sinn, H.-W. (1987), Capital Income Taxation and Resource Allocation, Amsterdam, North-Holland.

Sinn, H.-W., W. Leibfritz and A. Weichenrieder (1999), ifo Vorschlag zur Steuerreform, ifo Schnelldienst 52: 3-18.

Smith, C. W. and J. B. Warner (1979), On Financial Contracting: An Analysis of Bond Covenants, Journal of Financial Economics 7: 117-161.

Stohs, M. H. and D. C. Mauer (1996), The Determinants of Corporate Debt Maturity Structure, Journal of Business 69: 279-312.

Titman, S. (1992), Interest Rate Swaps and Corporate Financing Choice, Journal of Finance 47: 1503-1516.

Titman, S. and R. Wessels (1988), The Determinants of Capital Structure Choice, Journal of Finance 43: 1-19.

Whited, T. M. (1992), Debt, Liquidity Constraints, and Corporate Investment: Evidence from Panel Data, Journal of Finance 47: 1425-1460. 


\section{CESifo Working Paper Series}

(for full list see www.cesifo.de)

1057 Carsten Hefeker, Structural Reforms and the Enlargement of Monetary Union, October 2003

1058 Henning Bohn and Charles Stuart, Voting and Nonlinear Taxes in a Stylized Representative Democracy, October 2003

1059 Philippe Choné, David le Blanc and Isabelle Robert-Bobée, Female Labor Supply and Child Care in France, October 2003

1060 V. Anton Muscatelli, Patrizio Tirelli and Carmine Trecroci, Fiscal and Monetary Policy Interactions: Empirical Evidence and Optimal Policy Using a Structural New Keynesian Model, October 2003

1061 Helmuth Cremer and Pierre Pestieau, Wealth Transfer Taxation: A Survey, October 2003

1062 Henning Bohn, Will Social Security and Medicare Remain Viable as the U.S. Population is Aging? An Update, October 2003

1063 James M. Malcomson, Health Service Gatekeepers, October 2003

1064 Jakob von Weizsäcker, The Hayek Pension: An efficient minimum pension to complement the welfare state, October 2003

1065 Joerg Baten, Creating Firms for a New Century: Determinants of Firm Creation around 1900, October 2003

1066 Christian Keuschnigg, Public Policy and Venture Capital Backed Innovation, October 2003

1067 Thomas von Ungern-Sternberg, State Intervention on the Market for Natural Damage Insurance in Europe, October 2003

1068 Mark V. Pauly, Time, Risk, Precommitment, and Adverse Selection in Competitive Insurance Markets, October 2003

1069 Wolfgang Ochel, Decentralising Wage Bargaining in Germany - A Way to Increase Employment?, November 2003

1070 Jay Pil Choi, Patent Pools and Cross-Licensing in the Shadow of Patent Litigation, November 2003

1071 Martin Peitz and Patrick Waelbroeck, Piracy of Digital Products: A Critical Review of the Economics Literature, November 2003 
1072 George Economides, Jim Malley, Apostolis Philippopoulos, and Ulrich Woitek, Electoral Uncertainty, Fiscal Policies \& Growth: Theory and Evidence from Germany, the UK and the US, November 2003

1073 Robert S. Chirinko and Julie Ann Elston, Finance, Control, and Profitability: The Influence of German Banks, November 2003

1074 Wolfgang Eggert and Martin Kolmar, The Taxation of Financial Capital under Asymmetric Information and the Tax-Competition Paradox, November 2003

1075 Amihai Glazer, Vesa Kanniainen, and Panu Poutvaara, Income Taxes, Property Values, and Migration, November 2003

1076 Jonas Agell, Why are Small Firms Different? Managers’ Views, November 2003

1077 Rafael Lalive, Social Interactions in Unemployment, November 2003

1078 Jean Pisani-Ferry, The Surprising French Employment Performance: What Lessons?, November 2003

1079 Josef Falkinger, Attention, Economies, November 2003

1080 Andreas Haufler and Michael Pflüger, Market Structure and the Taxation of International Trade, November 2003

1081 Jonas Agell and Helge Bennmarker, Endogenous Wage Rigidity, November 2003

1082 Fwu-Ranq Chang, On the Elasticities of Harvesting Rules, November 2003

1083 Lars P. Feld and Gebhard Kirchgässner, The Role of Direct Democracy in the European Union, November 2003

1084 Helge Berger, Jakob de Haan and Robert Inklaar, Restructuring the ECB, November 2003

1085 Lorenzo Forni and Raffaela Giordano, Employment in the Public Sector, November 2003

1086 Ann-Sofie Kolm and Birthe Larsen, Wages, Unemployment, and the Underground Economy, November 2003

1087 Lars P. Feld, Gebhard Kirchgässner, and Christoph A. Schaltegger, Decentralized Taxation and the Size of Government: Evidence from Swiss State and Local Governments, November 2003

1088 Arno Riedl and Frans van Winden, Input Versus Output Taxation in an Experimental International Economy, November 2003

1089 Nikolas Müller-Plantenberg, Japan’s Imbalance of Payments, November 2003 
1090 Jan K. Brueckner, Transport Subsidies, System Choice, and Urban Sprawl, November 2003

1091 Herwig Immervoll and Cathal O'Donoghue, Employment Transitions in 13 European Countries. Levels, Distributions and Determining Factors of Net Replacement Rates, November 2003

1092 Nabil I. Al-Najjar, Luca Anderlini \& Leonardo Felli, Undescribable Events, November 2003

1093 Jakob de Haan, Helge Berger and David-Jan Jansen, The End of the Stability and Growth Pact?, December 2003

1094 Christian Keuschnigg and Soren Bo Nielsen, Taxes and Venture Capital Support, December 2003

1095 Josse Delfgaauw and Robert Dur, From Public Monopsony to Competitive Market. More Efficiency but Higher Prices, December 2003

1096 Clemens Fuest and Thomas Hemmelgarn, Corporate Tax Policy, Foreign Firm Ownership and Thin Capitalization, December 2003

1097 Laszlo Goerke, Tax Progressivity and Tax Evasion, December 2003

1098 Luis H. B. Braido, Insurance and Incentives in Sharecropping, December 2003

1099 Josse Delfgaauw and Robert Dur, Signaling and Screening of Workers' Motivation, December 2003

1100 Ilko Naaborg,, Bert Scholtens, Jakob de Haan, Hanneke Bol and Ralph de Haas, How Important are Foreign Banks in the Financial Development of European Transition Countries?, December 2003

1101 Lawrence M. Kahn, Sports League Expansion and Economic Efficiency: Monopoly Can Enhance Consumer Welfare, December 2003

1102 Laszlo Goerke and Wolfgang Eggert, Fiscal Policy, Economic Integration and Unemployment, December 2003

1103 Nzinga Broussard, Ralph Chami and Gregory D. Hess, (Why) Do Self-Employed Parents Have More Children?, December 2003

1104 Christian Schultz, Information, Polarization and Delegation in Democracy, December 2003

1105 Daniel Haile, Abdolkarim Sadrieh and Harrie A. A. Verbon, Self-Serving Dictators and Economic Growth, December 2003

1106 Panu Poutvaara and Tuomas Takalo, Candidate Quality, December 2003 
1107 Peter Friedrich, Joanna Gwiazda and Chang Woon Nam, Development of Local Public Finance in Europe, December 2003

1108 Silke Uebelmesser, Harmonisation of Old-Age Security Within the European Union, December 2003

1109 Stephen Nickell, Employment and Taxes, December 2003

1110 Stephan Sauer and Jan-Egbert Sturm, Using Taylor Rules to Understand ECB Monetary Policy, December 2003

1111 Sascha O. Becker and Mathias Hoffmann, Intra-and International Risk-Sharing in the Short Run and the Long Run, December 2003

1112 George W. Evans and Seppo Honkapohja, The E-Correspondence Principle, January 2004

1113 Volker Nitsch, Have a Break, Have a ... National Currency: When Do Monetary Unions Fall Apart?, January 2004

1114 Panu Poutvaara, Educating Europe, January 2004

1115 Torsten Persson, Gerard Roland, and Guido Tabellini, How Do Electoral Rules Shape Party Structures, Government Coalitions, and Economic Policies? January 2004

1116 Florian Baumann, Volker Meier, and Martin Werding, Transferable Ageing Provisions in Individual Health Insurance Contracts, January 2004

1117 Gianmarco I.P. Ottaviano and Giovanni Peri, The Economic Value of Cultural Diversity: Evidence from US Cities, January 2004

1118 Thorvaldur Gylfason, Monetary and Fiscal Management, Finance, and Growth, January 2004

1119 Hans Degryse and Steven Ongena, The Impact of Competition on Bank Orientation and Specialization, January 2004

1120 Piotr Wdowinski, Determinants of Country Beta Risk in Poland, January 2004

1121 Margarita Katsimi and Thomas Moutos, Inequality and Redistribution via the Public Provision of Private Goods, January 2004

1122 Martin Peitz and Patrick Waelbroeck, The Effect of Internet Piracy on CD Sales: CrossSection Evidence, January 2004

1123 Ansgar Belke and Friedrich Schneider, Privatization in Austria: Some Theoretical Reasons and First Results About the Privatization Proceeds, January 2004

1124 Chang Woon Nam and Doina Maria Radulescu, Does Debt Maturity Matter for Investment Decisions?, February 2004 